\title{
THE DISINTEGRATION OF POPULATIONS OF UNDERWATER PLANTS IN SOFT WATER LAKES ENRICHED WITH ACIDIC ORGANIC MATTER
}

\author{
JÓZEF SZMEJA, KATARZYNA BOCIĄG \\ Department of Plant Ecology, University of Gdańsk \\ Al. Legionów 9, 80-441 Gdańsk, Poland \\ e-mail:dokkb@univ.gda.pl
}

(Received: June 15, 2003. Accepted: March 4, 2004)

\begin{abstract}
The characteristics of habitats, individuals and populations of four submerged macrophytes, Lobelia dortmanna L., Isoëtes lacustris L., Sphagnum denticulatum Brid. and Fontinalis antipyretica Hedw., were studied in 12 soft water oligohumic lakes which had no inflow of allochtonic DOM and the DOC concentration in the water was $<4.0 \mathrm{mg} \mathrm{C} \mathrm{dm}^{-3}$ and 13 humic lakes enriched with allochthonous dissolved organic matter (DOM) from drained peat bogs and ranging in DOC water concentration from 4.1 to $44.0 \mathrm{mg} \mathrm{C} \mathrm{dm}^{-3}$. The analyses of population disintegration were conducted basing on characteristics of individuals (size, habitat, fertility) and populations (aggregation density index, settlement index of the population area). The settlement index of the population area for Lobelia, Fontinalis, Isoëtes, Sphagnum decreased from 8.4 to $6.2 \mathrm{~g} \mathrm{d.w.} \mathrm{m}^{-2}, 4.6$ to $0.01 \mathrm{~g} \mathrm{~d} . \mathrm{w} . \mathrm{m}^{-2}, 85.4$ to $<0.001 \mathrm{~g} \mathrm{~d}$.w. $\mathrm{m}^{-2}$ and 39.3 to $7.2 \mathrm{~g} \mathrm{~d} . \mathrm{w} . \mathrm{m}^{-2}$, respectively. Similar trends were observed in aggregation density. The general pattern of the disintegration of populations of these species was always similar. It was independent of the source macrophytes drew resources from or their susceptibility to environmental changes. Individuals began to be eliminated from the deep and central parts of the population area. The remainder of the populations, which persist in the shallowest, best-illuminated part of the area, are themselves endangered by disturbances caused by wavy motion. The only populations of submerged macrophytes which can survive in polyhumic lakes under such conditions are those which are resistant to disturbances common in the shallow littoral (Lobelia dortmanna, Fontinalis antipyretica).
\end{abstract}

KEY WORDS: soft water lakes, macrophytes, DOM, disturbance, population structure, Isoëtes lacustris, Lobelia dortmanna, Sphagnum denticulatum, Fontinalis antipyretica.

\section{INTRODUCTION}

Dissolved organic matter (DOM) is a natural factor which significantly influence environmental conditions in lakes throughout vast areas of the northern hemisphere (Wetzel 1983; Curtis 1998). However, humication, i.e. enrichment with allochthonous DOM, from drained swamps and bogs has been a common and long-term form of anthropogenic pressure on lakes (in NW Poland for almost 200 years; Szmeja 2000; Bociąg and Szmeja 2001). DOM-rich waters are discharged into lakes through systems of drainage ditches. Frequent and heavy inputs, especially in spring and autumn, cause changes in lake water color that range from yellow to dark brown.

The DOM, which originates from peat bogs, primarily consists of humic substances (Thurman 1985). Humic substances (HS) absorb a portion of solar radiation (Frimmel 1994), including UV (Schindler et. al. 1996). They also acidify the water (Gorham et. al. 1986; Kulberg et. al. 1993) and affect trophic conditions by complexing phosphate ions (Stewart and Wetzel 1983; De Haan 1992), which, after release, for example by UV radiation, can be bonded by plants. HS have strong complexing properties, and, in addition to phosphates, they also bond ammonium ions and metal cations (Kinniburgh et al. 1996). This results in the creation of mineral-humic complexes that settle and change the chemical composition of bottom sediments and block microelements which are necessary for organisms (Guildford et al. 1987).

In recent years there has been significant interest in studying the genesis and role of DOM, particularly HS, in lake ecosystems as well as investigating chemical processes which occur in water and sediments (Hessen and Tranvik 1998; McKnight and Aiken 1998; Keskitalo and Eloranta 1999). Progress in these fields facilitates undertaking detailed studies of plants in lakes that are enriched with DOM. If the effects of lake humication are not identified, protecting these valuable ecosystems will not be fully successful.

Underwater vegetation in lakes is not very resistant to the pressure resulting from the majority of human activities, including humication (Szmeja 2000; Bociąg and Szmeja 2001). One reason for this is the structure of aquatic vegetation communities. Underwater vegetation is comprised of a small number of species that usually tend to form single-species aggregations. Therefore, the vegetation has a synusial structure similar to that observed in other ty- 
pes of ecosystems (Faliński and Venanzoni 1991; Gillet and Gallandt 1996). However, in no other ecosystem is the vegetation structure as simple or has as few species as aquatic ecosystems do. The main element of this structure are dominant aggregations. They have their own rhythm of variations in abundance and density (Szmeja 1994a, b). As such, they are not only structural, but also functional vegetation units. Therefore, the aggregation density and the settlement index of the population area are useful characteristics in the study of the mechanisms of the disintegration of underwater plants populations that are under anthropogenic pressure.

It was presumed that since the dominant macrophytes in soft water lakes have diverse plasticity reaction patterns and life strategies, in the sense that Grime proposed (1979), the extinction of species will vary in lakes supplied with DOM. It is hypothesized that the intensity of population collapse in lakes enriched with allochthonous acidic DOM depends on the degree of habitat transformation, the location in the littoral of the population area and life strategy of the species. It was also the intention of this paper to determine whether species with similar weight allocation, react similarly to increases of acidic DOM in the lakes. According to Stearns (1992), the allocation of resources to the organs (leaves, shoots and roots), the size of the individual (weight) and the number of progeny (seeds, spores) are all characteristics that are used to compare the life histories of species.

\section{METHODS}

The features of individuals and the population structure of underwater plants were studied in two categories of soft water, oligotrophic lakes: (1) without a significant contribution of allochthonous DOM; (2) with inputs of DOM from the drainage of peat-bogs. The study focused on the habitats, individual plasticity and population structure of the following four dominants: Isoëtes lacustris; Lobelia dortmanna; Sphagnum denticulatum; Fontinalis antipyretica. The first two species are isoetids, which draw nutritional substances from the sediments and are characterized by their own specific allocation of weight to their organs and with a large percentage of their biomass underground (Szmeja 1994a, b). The other two species are bryophytes which draw their nourishment from the water and locate most of their weight in assimilation surfaces.

Field work was conducted in 25 lakes in the Pomeranian Region (NW Poland) in July from 1996 to 2002. Populations in two lake groups were selected for the study. The first group included 12 oligohumic lakes which had neither an inflow of allochtonic DOM nor a significant contribution from surrounding peat bogs and the DOC concentration in the water was $<4.0 \mathrm{mg} \mathrm{C} \mathrm{dm}^{-3}$. The second group included 13 humic lakes that received water from peat bogs through drainage canals. This group was divided into three categories according to the DOC concentration in the water, as follows (Szmeja 2000): $\alpha$-mesohumic lakes (water DOC concentration 4.1-8.0 $\mathrm{mg} \mathrm{C} \mathrm{dm}^{-3}$ ); $\beta$-mesohumic (8.1-16.0 $\mathrm{mg} \mathrm{C} \mathrm{dm}^{-3}$ ); polyhumic lakes (>16.0 $\left.\mathrm{mg} \mathrm{C} \mathrm{dm}^{-3}\right)$.

The habitat conditions, the features of individuals and the population structure of the dominant species were studied in each lake. The study included the following: size, fertility and the allocation of weight in the organs (leaves, shoots, roots) of the dominant species (with the exception of Sphagnum denticulatum); species frequency (\%); settlement index of the population area $\left(\mathrm{g} \mathrm{d} . \mathrm{w} . \mathrm{m}^{-2}\right)$; aggregation density index (g d.w. $0.1 \mathrm{~m}^{-2}$ ).

The size and fertility of generative individuals of Isoëtes and Lobelia and the size of mature individuals of Fontinalis were studied. A total of 324 individuals were collected by randomly selecting 30 individuals from the center of the population areas of these species. The following was studied in Isoëtes: number of leaves in the rosette, leaf length, number of macro- and microsporangia, number of macrospores in the macrosporangia, dry weight of leaves, rhizomes and rhizoids. The studied biometric features of Lobelia included the number of leaves in the rosette, leaf length, the number of flowers and fruit, the number of seeds in the fruit, dry weight of leaves, rhizomes and roots. The following was studied in Fontinalis: shoot length; weight; the number of side shoots.

The structures of the populations were studied in a 50 $\mathrm{m}$ long area of each population. The width of the study area depended on the maximum depth at which any dominant occurred. Thus, complete deep range of the population area (from the upper to the lower population area border) was taken into consideration. Each study area was divided into $1 \mathrm{~m}$ depth zones. In these zones plant samples were collected (while diving) from 10 plots of $0.1 \mathrm{~m}^{2}$ at 2.5 $\mathrm{m}$ intervals. A total of 1837 samples were collected. The samples were sorted by species, dried at $95^{\circ} \mathrm{C}$ and then weighed. The samples collected served to determined the following: dominant frequency (F [\%]); the limits of its population area $[\mathrm{m}]$; settlement index $\left(\mathrm{I}_{\mathrm{S}}\left[\mathrm{g}\right.\right.$ d.w. $\left.\left.\mathrm{m}^{-2}\right]\right)$; the aggregation density index $\left(\mathrm{I}_{\mathrm{D}}\left[\mathrm{g}\right.\right.$ d.w. $\left.\left.0.1 \mathrm{~m}^{-2}\right]\right)$. Frequency was calculated using the following formula: $\mathrm{F}=$ $\left(\mathrm{n}_{\mathrm{z}} / \Sigma \mathrm{n}_{\mathrm{T}}\right) \times 100 \%$, where: $\mathrm{n}_{\mathrm{Z}}-$ number of samples in which the dominant species occurred; $\mathrm{n}_{\mathrm{T}}$ - total number of samples. The settlement index was calculated as follows: $\mathrm{I}_{\mathrm{S}}=\Sigma \mathrm{m} / \mathrm{n}_{\mathrm{T}}$, where: $\mathrm{m}$ - biomass of the dominant species in the sample; $\mathrm{n}_{\mathrm{T}}$ - total number of samples. „Empty” samples were included in the calculations. The aggregation density index of the dominant species is the arithmetic average of its biomass in the samples it occurred in. This index was calculated as follows: $I_{D}=\Sigma m / n$, where: $\mathrm{m}$ - biomass of the dominant species in a sample; $\mathrm{n}$ - number of samples with this species.

Samples of surface water, the water directly above the sediments and the sediments (0-10 cm layer) were collected in order to describe habitats. The water from directly above the sediments and the sediment samples were collected by divers in the littoral at depth increments of $1 \mathrm{~m}$. Surface water samples were used to determine color and DOC. The color of the water was determined by the comparative method according to the platinum-cobalt scale. The DOC concentration in filtered water was determined spectrophotometrically by measurements at $\lambda=260$ and $330 \mathrm{~nm}$ (Moore 1987). The concentration of DOC was accepted as the DOM content of the water. Secchi disc visibility was also determined. The $\mathrm{pH}$, conductivity, calcium concentration (by titration), total nitrogen and phosphorus content (spectrophotometrically according to Clesceri et al. (1989)) were determined for the filtered samples of water from directly above the sediments. The $\mathrm{pH}$, redox potential, calcium content, phosphorus and total nitrogen were determined for 
the sediment samples using the same methods as applied to the water samples. Additionally, the hydration, organic matter content and the humic acid concentrations (using extraction and the determination of oxidable OC following the modified method of Tiurin according to Górniak (1996)) were also determined.

The hypotheses regarding the significance of the differences between these features were verified using the ANOVA variance analysis method. In cases when the assumptions were not confirmed, the nonparametric Kruskal-Wallis test (for $\mathrm{P}<0.05$; Kruskal and Wallis 1952) was applied. Correlations between features were studied at $\mathrm{P}<0.01$.

\section{RESULTS}

\section{Habitat conditions}

The fundamental characteristic of the underwater plants' habitats in the oligohumic lakes is the low content of DOM in the water (Table 1). This means that the water is almost colorless, the littoral is well illuminated and the underwater vegetation habitats reach depths of up to $12 \mathrm{~m}$. They have a wide $\mathrm{pH}$ range in the layer directly above the sediments ( $\mathrm{pH}$ 4.0-7.5; $\mathrm{Me}=5.3$ ), their conductivity is low and the calcium content is very low (in water $1.3-11.6 \mathrm{mg} \mathrm{dm}^{-3}$, $\mathrm{Me}=3.5$ ). In the shallow parts of the habitats (up to 3 $\mathrm{m}$ deep) the soil is mineral, badly hydrated and poor in HS, what suggests a strong erosion by waves. At depths greater than $3 \mathrm{~m}$, the bottom is covered by accumulation sediment. As a result, the sediment is more hydrated and richer in organic substances, including humic substances.

The meso- and polyhumic lakes have distorted hydrologic systems in the drainage areas and they are altered by the inflow of allochtonic DOM from various types of bogs. The underwater plants' habitats of meso- and polyhumic lakes differ primarily from those in oligohumic lakes in that there are higher concentrations of DOC in their waters $(\mathrm{P}<0.05$; Table 1). As a result, the water color is stronger $(\mathrm{P}<0.001)$, visibility is worse $(\mathrm{P}<0.001)$ and the total nitro- gen content is higher $(\mathrm{P}<0.05)$. These characteristics are statistically significantly correlated with the DOC content in the water $(\mathrm{r}=0.92, \mathrm{r}=-0.51, \mathrm{r}=0.62 ; \mathrm{P}<0.01$, respectively). In comparison with oligohumic habitats, the conductivity of the water directly above the sediments is higher $(\mathrm{P}<0.05)$, while the calcium content in the sediments is lower $(\mathrm{P}<0.05)$ and that of nitrogen is higher $(\mathrm{P}<0.05)$. The stronger colored water means that the bottoms of lakes are more poorly illuminated. This causes the lower habitat border to shift towards the shallower areas near the shores that are more disturbed by waves. In mesohumic lakes, this border is usually located at a depth of $3 \mathrm{~m}$, while in oligohumic lakes it is at $9.5 \mathrm{~m}$. The location of the border is strongly correlated with the DOC content in water $(r=-0.7$, $\mathrm{P}<0.01)$ and habitat features which are modified by DOM, such as visibility, water color and nitrogen concentration. Therefore, meso- and polyhumic habitats are much narrower and are located in the shallow littoral where the soil is less hydrated and contains less organic matter $(\mathrm{P}<0.05$; Table 1).

Allocation of weight, plasticity of individuals and population structure

\section{ISOËTES LACUSTRIS}

Isoëtes lacustris is an perennial, evergreen plant that anchors to the bottom and grows at a vast range of depths in soft water lakes. In oligohumic lakes, the sporogenous individual from the center of the population area (depth of 1$-3 \mathrm{~m})$ is large $(0.39 \pm 0.1 \mathrm{~g} \mathrm{~d} . \mathrm{w}$.; Fig. 1). Its rosette consists of many long leaves, and the proportion of the mass of underground organs (bulbous stem and roots) to aboveground (leaves) is $0.26 \pm 0.08$. The leaves usually comprise $70 \%$ of the individual mass. Every third leaf in the rosette creates sporangia, and there are almost as many macrosporangia as microsporangia $(4.4 \pm 1.8$ vs $4.0 \pm 2.0)$. There are $71 \pm 22$ macrospores in the macrosporangium.

In meso- and polyhumic lakes, the individuals are smaller and lighter than those in oligohumic ones (Fig. 1): plant

TABLE 1. Features of habitats in oligo-, meso- and polyhumic lakes. $\mathrm{n}$ - number of samples, Me - median mean, min.-max - range

\begin{tabular}{|c|c|c|c|c|c|c|c|c|}
\hline \multirow[b]{2}{*}{ Feature } & \multicolumn{4}{|c|}{ Oligohumic lakes } & \multicolumn{4}{|c|}{ Meso- and Polyhumic lakes } \\
\hline & $\mathrm{n}$ & Mean \pm S.D. & $\mathrm{Me}$ & $\min .-\max$ & $\mathrm{n}$ & Mean \pm S.D. & $\mathrm{Me}$ & $\min .-\max$ \\
\hline \multicolumn{9}{|c|}{ Water } \\
\hline Secchi disc $[\mathrm{m}]$ & 12 & $5.6 \pm 2.0$ & 5 & $4-11$ & 13 & $1.6 \pm 0.9$ & 1.5 & $0.5-3.5$ \\
\hline Color [mg Pt dm ${ }^{-3}$ ] & 12 & $5.0 \pm 4.8$ & 4.5 & $0-17$ & 13 & $125 \pm 161$ & 60 & $13-600$ \\
\hline $\mathrm{DOC}\left[\mathrm{mg} \mathrm{C} \mathrm{dm}^{-3}\right]$ & 12 & $2.9 \pm 1.25$ & 2.5 & $1.8-3.9$ & 13 & $13.5 \pm 12.5$ & 8.5 & $4.7-44.0$ \\
\hline $\mathrm{pH}$ & 115 & $5.5 \pm 1.0$ & 5.3 & $4-7.5$ & 42 & $5.4 \pm 1.1$ & 4.5 & $4.2-7.6$ \\
\hline$\chi\left[\mu \mathrm{S} \mathrm{cm}^{-1}\right]$ & 115 & $48.4 \pm 15.5$ & 46 & $26 \pm 81$ & 42 & $53.6 \pm 13.9$ & 47.4 & $36-80$ \\
\hline $\mathrm{Ca}\left[\mathrm{mg} \mathrm{dm}^{-3}\right]$ & 115 & $4.0 \pm 2.9$ & 3.5 & $1.3-11.6$ & 42 & $4.2 \pm 2.6$ & 3.0 & $1.2-11.5$ \\
\hline $\mathrm{P}_{\text {tot }}\left[\mathrm{mg} \mathrm{dm}^{-3}\right]$ & 115 & $0.11 \pm 0.04$ & 0.10 & $0.06-0.23$ & 42 & $0.13 \pm 0.12$ & 0.10 & $0.07-0.90$ \\
\hline $\mathrm{N}_{\text {tot }}\left[\mathrm{mg} \mathrm{dm}^{-3}\right]$ & 115 & $1.22 \pm 0.49$ & 1.13 & $0.46-3.0$ & 42 & $2.7 \pm 1.4$ & 2.5 & $0.87-6.04$ \\
\hline
\end{tabular}

Sediment

\begin{tabular}{|c|c|c|c|c|c|c|c|c|}
\hline $\mathrm{pH}$ & 115 & $5.9 \pm 0.5$ & 5.9 & 4.4-6.9 & 42 & $5.8 \pm 0.5$ & 5.8 & $4.5-6.9$ \\
\hline Potential [mV] & 115 & $-116 \pm 174$ & -175 & $-340-358$ & 42 & $-159 \pm 163$ & -213 & $-337-354$ \\
\hline $\mathrm{Ca}\left[\mathrm{mg}\right.$ g d.w..$\left.^{-1}\right]$ & 115 & $4.3 \pm 2.6$ & 3.6 & $1-16$ & 42 & $3.2 \pm 1.9$ & 2.75 & $0.4-10.4$ \\
\hline $\mathrm{P}_{\mathrm{tot}}\left[\mathrm{mg} \mathrm{g} \mathrm{d.w.}^{-1}\right]$ & 115 & $3.79 \pm 7.59$ & 0.28 & $0.03-38.79$ & 42 & $3.34 \pm 6.4$ & 0.27 & $0.06-26.4$ \\
\hline $\mathrm{N}_{\text {tot }}\left[\mathrm{mg} \mathrm{g} \mathrm{d.w.} .^{-1}\right]$ & 115 & $10.4 \pm 8.3$ & 6.7 & $1.6-32.5$ & 42 & $14.8 \pm 12.7$ & 8.38 & $3.4-44.5$ \\
\hline HS [mg g d.w..$\left.^{-1}\right]$ & 115 & $38.0 \pm 34.6$ & 26.8 & $1.9-138.7$ & 42 & $43.2 \pm 46.2$ & 28.1 & $1.8-155.8$ \\
\hline Hydration [\%] & 115 & $52.8 \pm 27.6$ & 48 & $14-95$ & 42 & $48.1 \pm 29.9$ & 33.5 & $15-94$ \\
\hline Organic matter [\%] & 115 & $30.3 \pm 28.5$ & 20.3 & $0.2-90.2$ & 42 & $19.1 \pm 23.2$ & 4.6 & $0.21-75.7$ \\
\hline
\end{tabular}



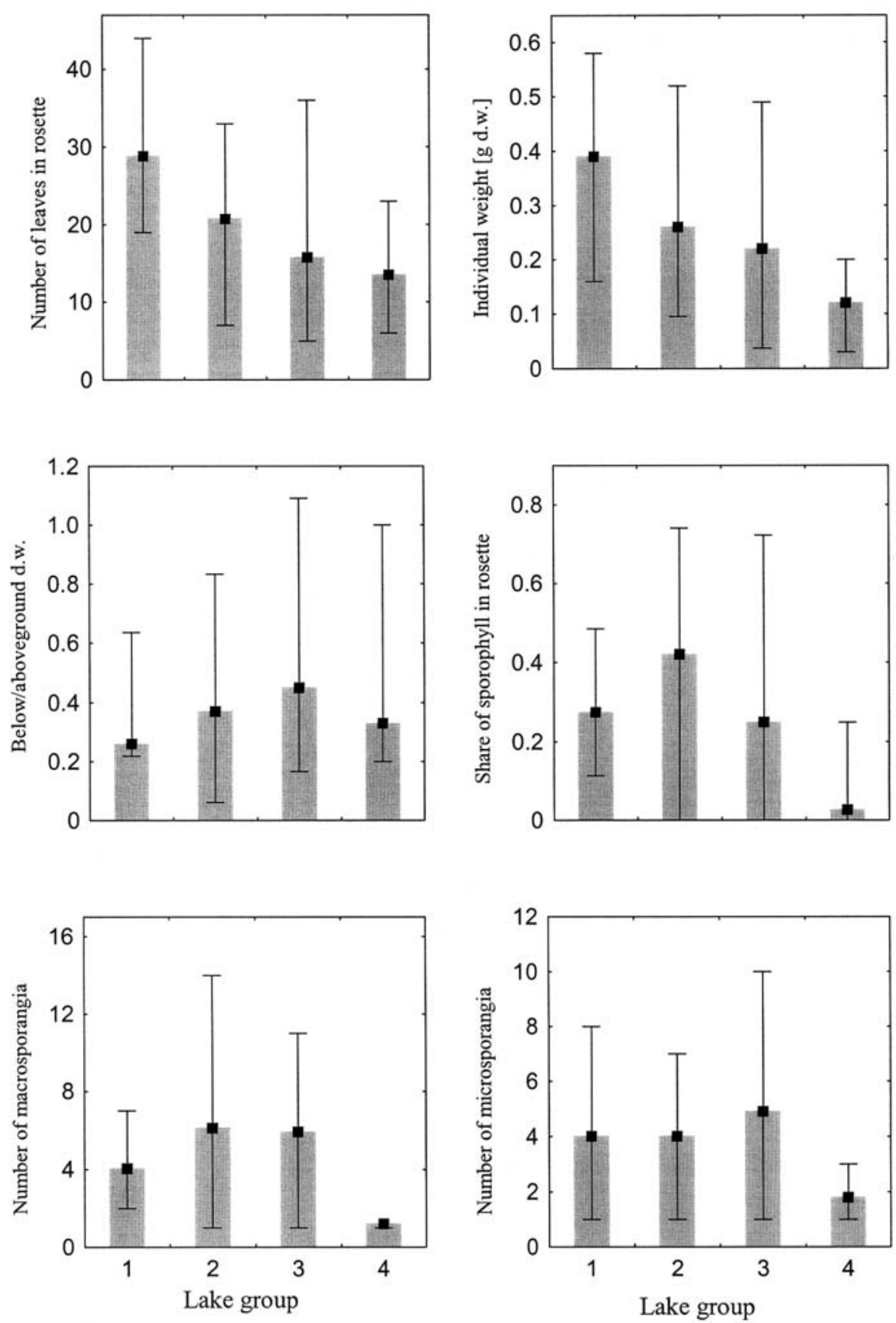

Fig. 1. Features of Isoëtes lacustris from oligo(1), $\alpha$-meso- (2), $\beta$-meso- (3) and polyhumic lakes (4). - arithmetic mean, I - range.

weight for polyhumic lakes was $0.12 \pm 0.05 \mathrm{~g} \mathrm{~d} . \mathrm{w}$. $(\mathrm{P}<0.001)$, which is related to a reduction in assimilation area. In samples from oligo- to polyhumic lakes, the number of leaves in the rosette decreases from $29 \pm 7$ to $13 \pm 4$; this is correlated with an increase of DOC concentration in water $(r=-0.44)$ and sediment features. However, leaf length does not change significantly statistically. In individuals from meso- and polyhumic lakes the ratio of underground to aboveground mass is greater (in oligohumic lakes 0.26 , in $\beta$-mesohumic $0.45 ; \mathrm{P}<0.05$ ). This is correlated with sediment hydration and the DOC content in water $(r=0.4)$. These large differences are caused by a slightly different allocation of resources. The percentage of the bulbous stem to the individual biomass becomes greater and greater. This may result from the increasing number of older individuals in the population as the recruitment of younger ones is halted. In meso- and polyhumic lakes there are fewer sporogenous individuals, but the share of sporo- phyll in the rosette of an average generative individual is the highest in populations from $\alpha$-mesohumic lakes $(0.42 \pm 0.15$ vs $0.28 \pm 0.1$ in oligohumic lakes, $\mathrm{P}<0.05)$. This results from the greater number of macrosporangia in the rosettes from individuals in $\alpha$-mesohumic lakes $(6.1 \pm 3.5 \mathrm{vs}$ $4.4 \pm 1.8, \mathrm{P}<0.05)$ and the probable slower growth rate of young leaves. In polyhumic lakes (DOC $>16 \mathrm{mg} \mathrm{C} \mathrm{dm}^{-3}$ ), the fertility of individuals decreases significantly. Individuals which grow in polyhumic lakes, in comparison with those from $\beta$-mesohumic lakes, produce far fewer microsporangia $(1.8 \pm 1.1$ vs $4.9 \pm 3.5, \mathrm{P}<0.001)$. Equally strong is the reduction in the number of macrosporangia $(1.2 \pm 0.45$ vs $4.9 \pm 2.6, \mathrm{P}<0.001)$ and in number of macrospores in the macrosporangium $(32.7 \pm 7.7$ vs $71.4 \pm 22.4$; $\mathrm{P}<0.001)$.

Isoëtes occurs in oligohumic lakes at a high frequency $(73.7 \pm 16.8 \%)$ and usually grows at depths of up to 5-6 m. The settlement and aggregation density indexes are high, on average $\left(85.4 \pm 53.8 \mathrm{~g} \mathrm{~d} . \mathrm{w} . \mathrm{m}^{-2}\right.$ and $11.4 \pm 12.9 \mathrm{~g} \mathrm{~d} . \mathrm{w} .0 .1 \mathrm{~m}^{-2}$, 


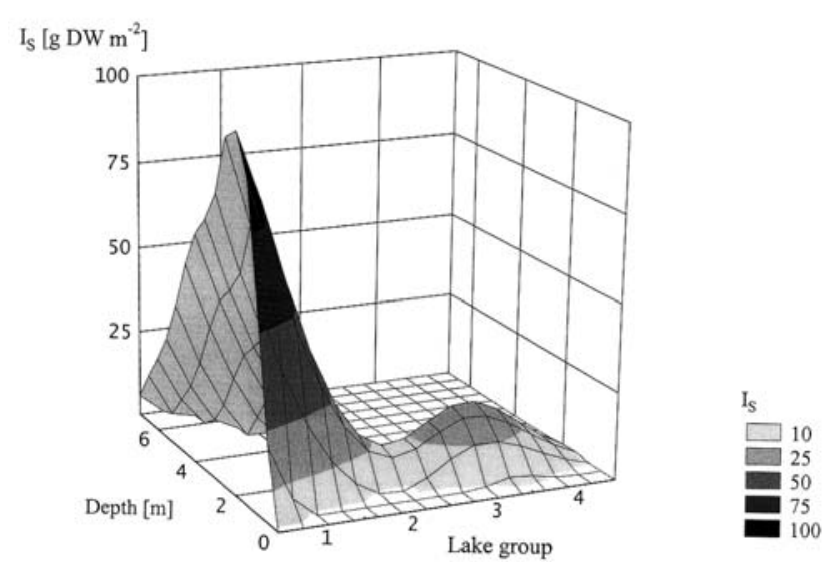

Fig. 2. Model of changes in Isoëtes lacustris populations in lakes ranging from oligo- (1) to polyhumic (4). $\mathrm{I}_{\mathrm{S}}-$ settlement index of the population area.

respectively); however, they are highly variable at 0.08 $-421.4 \mathrm{~g} \mathrm{~d} . \mathrm{w} . \mathrm{m}^{-2}$ and 0.01-66 g d.w. $0.1 \mathrm{~m}^{-2}$, respectively. The following three depth zones can be seen in the population area: shallow (0-1 m); central (1-3 m); deep (>5 m). Frequency is high in the shallow zone $(69 \%)$, but the individuals are scattered or they form small aggregations, and thus $I_{S}$ and $I_{D}$ have low values at $24.7 \pm 31.0 \mathrm{~g} \mathrm{~d} . \mathrm{w} . \mathrm{m}^{-2}$ and $4.2 \pm 5.9 \mathrm{~g}$ d.w. $0.1 \mathrm{~m}^{-2}$, respectively. The plant is even more scattered in the deep area (at $\mathrm{F}$ of $12 \%$ and a $\mathrm{I}_{\mathrm{S}}$ of $2.0 \pm 2.8 \mathrm{~g} \mathrm{~d} . \mathrm{w} . \mathrm{m}^{-2}$ ), while in the central part it forms vast, dense fields where $\mathrm{F}, \mathrm{I}_{\mathrm{S}}$ and $\mathrm{I}_{\mathrm{D}}$ are very high at $81.2 \pm 30.7 \%$, 104.9 $\pm 108.1 \mathrm{~g} \mathrm{~d} . \mathrm{w} . \mathrm{m}^{-2}$ and $14.3 \pm 12.7 \mathrm{~g} \mathrm{~d}$.w. $\mathrm{m}^{-2}$, respectively (Fig. 2).

The structural population features are significantly transformed in $\alpha$-meso-, $\beta$-meso- and polyhumic lakes. The population areas are increasingly narrower and reach depths of $4 \mathrm{~m}$ ( $\alpha$-mesohumic lakes), $3 \mathrm{~m}$ ( $\beta$-mesohumic) and $1 \mathrm{~m}$ (polyhumic lakes). The depth to which Isoëtes occurs is strongly correlated with DOC content in the water $(\mathrm{r}=-0.86)$, as well as with water color and visibility $(r=-0.66$ and -0.70$)$. As the DOM content increases in these lake types, the frequency of species and settlement index decrease. In oligohumic lakes $\mathrm{I}_{\mathrm{S}}$ is $85.4 \pm 53.8 \mathrm{~g} \mathrm{~d}$.w. $\mathrm{m}^{-2}$, while in polyhumic lakes it is lower than $0.001 \mathrm{~g} \mathrm{~d} . \mathrm{w} . \mathrm{m}^{-2}(\mathrm{P}<0.05)$. $\mathrm{I}_{\mathrm{D}}$ also decreases; in oligohumic lakes it is $11.4 \pm 12.9 \mathrm{~g} \mathrm{~d} . \mathrm{w} .0 .1 \mathrm{~m}^{-2}$, while in polyhumic it is $0.46 \pm 0.31 \mathrm{~g} \mathrm{~d} . \mathrm{w} .0 .1 \mathrm{~m}^{-2}$ $(\mathrm{P}<0.001)$. These differences are especially apparent in the central part of the population area in mesohumic lakes where each of the indices has values several ten-fold lower than in oligohumic lakes. The distribution of the studied plant also changes. Isoëtes occurs in small aggregations in mesohumic lakes and even in the central part of the area it does not form fields; it also covers an area several times smaller that that in oligohumic lakes. Reductions in the abundance and density of the population are so significant in polyhumic lakes that it is impossible to distinguish the shallow, central and deep parts of the area. Plants grow close to the shore and they are widely scattered (frequency $<10 \%$; Fig. 2).

\section{LOBELIA DORTMANNA}

In oligohumic lakes the average generative individual is large, i.e. heavy $(0.29 \pm 0.09 \mathrm{~g}$ d.w.) and has many leaves $(19.6 \pm 3.8)$ that are long $(4.3 \pm 1.4 \mathrm{~cm})$. The allocation of mass to the underground organs is similar to that in the aboveground organs. The leaves constitute $47 \%$, roots $33 \%$, and rhizomes $20 \%$ of the individual mass. There are $4.9 \pm 1.1$ flowers and fruit in the inflorescence. There are between 117 and 469 seeds in the fruit (Fig. 3).

In $\alpha$-mesohumic lakes the individuals are of a similar size to that in oligohumic lakes, and the differences in individual mass, numbers of leaves and their length are statistically insignificant, which differs from the case of Isoëtes lacustris. The further increase of DOM content causes small changes in the allocation of weight and fertility of individuals. In polyhumic lakes they are slightly lighter $(0.22 \pm 0.08 \mathrm{~g} \mathrm{~d}$. w.) and they have shorter leaves $(3.3 \pm 1.0$ $\mathrm{cm})$. In polyhumic lakes, as compared with those from oligohumic lakes, the ratio of the underground to aboveground parts of individuals is $1.16 \pm 0.3$ vs $1.23 \pm 0.53$, the contribution of rhizomes to the individual mass is $12 \pm 4 \% \mathrm{vs}$ $20 \pm 8 \%(\mathrm{P}<0.05)$ and the percentage of roots is greater at $40 \pm 7 \%$ vs $33 \pm 6 \%(\mathrm{P}<0.05)$. The individual fertility decreases slightly as the DOC concentration increases. In oligohumic lakes they produce an average of $4.9 \pm 1.1$ flowers and fruit, while in polyhumic lakes it is $3.8 \pm 1.6$. Additionally, there are fewer seeds in the fruit $(194.6 \pm 54 \mathrm{vs}$ $302.1 \pm 75 ; \mathrm{P}<0.001)$. Significant changes in the size and fertility of individuals occur above $16 \mathrm{mg} \mathrm{C} \mathrm{dm}^{-3}$ (Fig. 3).

The population areas in oligohumic lakes are located at depths of 0-2 (3) $\mathrm{m}$ and are well illuminated and agitated by waves. The frequency and settlement index are relatively high, $54.3 \pm 28.6 \%$ and $6.5 \pm 6.4 \mathrm{~g} \mathrm{~d} . \mathrm{w} . \mathrm{m}^{-2}$, respectively. In the shallow part of the area $(0-1 \mathrm{~m})$ this plant forms small aggregations $\left(I_{D}=2.2 \pm 2.0\right.$ g d.w. $\left.0.1 \mathrm{~m}^{-2}\right)$, but in deeper waters individuals are more widely scattered.

The range of the population area in mesohumic lakes is similar to that in oligohumic lakes. In the shallow littoral (0-1 m) of meso- and polyhumic lakes $\mathrm{F}, \mathrm{I}_{\mathrm{S}}$ and $\mathrm{I}_{\mathrm{D}}$ are similar to those in the analogous zone of oligohumic lakes. However, $\mathrm{F}(27.7 \pm 17.0 \%$ vs $54.3 \pm 28.6 \%$; $\mathrm{P}<0.05)$ and $\mathrm{I}_{\mathrm{S}}$ $\left(2.5 \pm 2.0\right.$ g d.w. $\mathrm{m}^{-2}$ vs $6.5 \pm 6.4$ g d.w. $\left.\mathrm{m}^{-2}\right)$ are lower throughout the area; this is caused by the reduction of aggregations in the deep part of the area. It is not until the DOC concentration increases above $16 \mathrm{mg} \mathrm{C} \mathrm{dm}^{-3}$ in polyhumic lakes that the population area narrows as its lower border shifts towards the shore, and in these lakes it reaches depths of up to $1 \mathrm{~m}$ (Fig. 4).

\section{FONTINALIS ANTIPYRETICA}

This moss has plagiotropic shoots which do not anchor in the sediments. In the central part of the population area in oligohumic lakes shoots are long $(21.8 \pm 5.5 \mathrm{~cm})$, heavy $(0.08 \pm 0.04 \mathrm{~g} \mathrm{d.w.})$ and have numerous side shoots (12.2 \pm 4.9$)$. The shoots of individuals in mesohumic lakes are shorter $(17.6 \pm 4.3 \mathrm{~cm})$, lighter $(0.04 \pm 0.03 \mathrm{~g} \mathrm{~d} . \mathrm{w}$.; $\mathrm{P}<0.05)$ and less ramate. Individuals from polyhumic lakes are the longest and heaviest $(27.9 \pm 7.05 \mathrm{~cm}, 0.23 \pm 0.17$ $\mathrm{g}$ d.w.; $\mathrm{P}<0.05)$, as well as the most ramate $(20.7 \pm 14.8)$. This response was confirmed only for Fontinalis.

The population areas in oligohumic lakes are very broad and are located at a depth range from 0 to $12 \mathrm{~m}$. The average frequency in the population area is $45.6 \pm 16.7 \%, \mathrm{I}_{\mathrm{S}}$ and $\mathrm{I}_{\mathrm{D}}$ are not high $\left(4.6 \pm 9.5 \mathrm{~g} \mathrm{d.w.} \mathrm{m}^{-2}\right.$ and $0.8 \pm 1.5 \mathrm{~g}$ d.w. $\left.0.1 \mathrm{~m}^{-2}\right)$. In the shallow part of the area $(0-3 \mathrm{~m})$ the frequency and settlement index are low $(15.7 \pm 9.3 \%$ and $0.16 \pm 0.16 \mathrm{~g} \mathrm{~d} . \mathrm{w} . \mathrm{m}^{-2}$, respectively). Individuals do not form aggregations and are scattered among the shoots of 

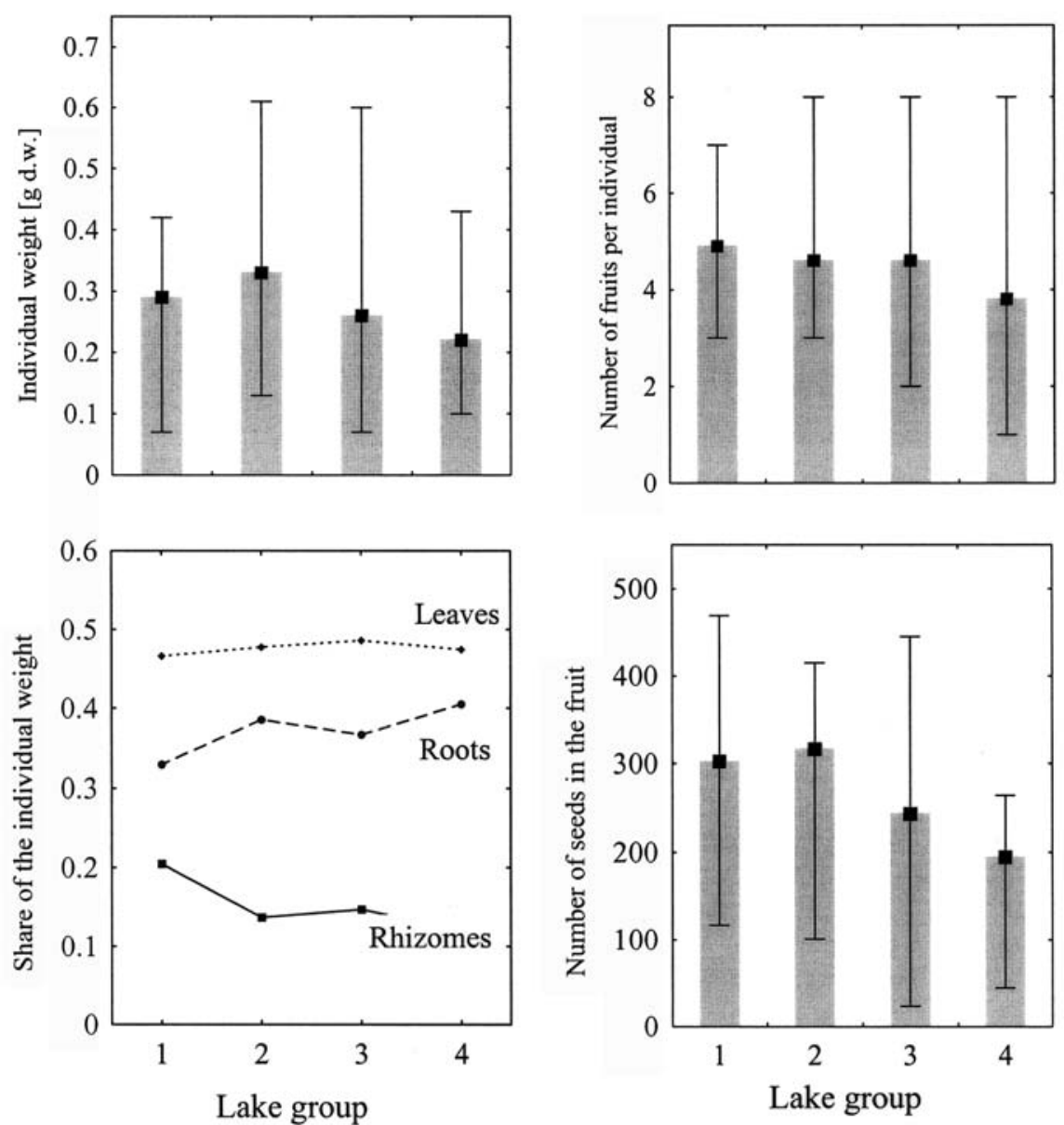

Fig. 3. Features of Lobelia dortmanna generative individuals from oligo- (1), $\alpha$-meso(2), $\beta$-meso- (3) and polyhumic lakes (4). - arithmetic mean, I - range. vascular plants, or they are attached to submerged stones and tree roots. The central part of the population area is vast (depths 3-8 $\mathrm{m}$ ) and is inhabited by numerous aggregations which cover small areas. The aggregation density index is $1.0 \pm 1.6 \mathrm{~g} \mathrm{~d} . \mathrm{w} .0 .1 \mathrm{~m}^{-2}$. The frequency and settlement index are higher in this zone in comparison with the shallow area $\left(68.8 \pm 31.5 \%\right.$ and $\left.5.4 \pm 6.6 \mathrm{~g} \mathrm{~d} . \mathrm{w} . \mathrm{m}^{-2}\right)$, while in the deepest zone $(8-12 \mathrm{~m})$ individuals grow in the greatest dispersion ( $\mathrm{F}, \mathrm{I}_{\mathrm{D}}$, and $\mathrm{I}_{\mathrm{S}}$ have the lowest values; Fig. 5).

The population areas in mesohumic lakes are located at depths from 0 to $6 \mathrm{~m}$. The frequency is lower than in oligo-
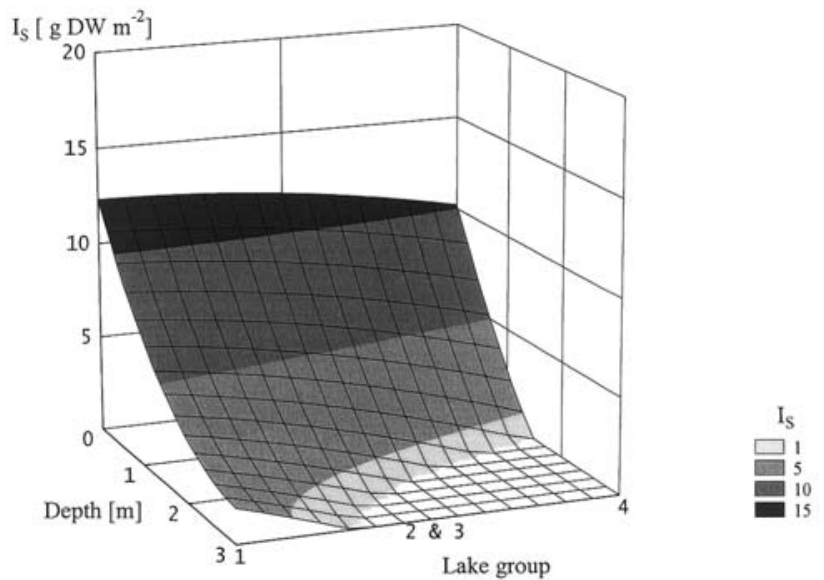

Fig. 4. Model of changes in Lobelia dortmanna populations in lakes ranging from oligo- (1) to polyhumic (4). $\mathrm{I}_{\mathrm{S}}$ - settlement index of the population area. humic lakes $(26.8 \pm 13.3 \%$ vs $45.6 \pm 16.7 \%)$, although $\mathrm{I}_{\mathrm{S}}$ and $\mathrm{I}_{\mathrm{D}}$ are higher $\left(8.5 \pm 18.3 \mathrm{~g} \mathrm{~d} . \mathrm{w} . \mathrm{m}^{-2}\right.$ and $2.3 \pm 6.2 \mathrm{~g}$ d.w. $\left.0.1 \mathrm{~m}^{-2}\right)$. Due to the narrower area located closer to the shores, the differences between central and shallow parts of the population are not very clear. Below the lower population area limit dead shoots occur, which are the remains of old aggregations. The optimum development conditions for Fontinalis in mesohumic lakes, indicated by the highest aggregations densities $\left(2.6 \pm 6.5 \mathrm{~g}\right.$ d.w. $\left.0.1 \mathrm{~m}^{-2}\right)$, were confirmed at depths 0-3 m, which were shallower than those in oligohumic lakes (3-10 m; Fig. 5).

The population areas in polyhumic lakes are located at depths of 0-0.5 m, i.e. much shallower than in the other lakes. The moss plants are scattered $(\mathrm{F}=3.3 \pm 5.8 \%)$ They are usually attached to submerged tree roots and have no contact with sediments. There are many dead or dying shoots.

\section{SPHAGNUM DENTICULATUM}

Sphagnum denticulatum is a perennial plant without roots which maintains contact with the sediments with the lower parts of its shoots. The population areas in oligohumic lakes are located at depths of 0-9 $\mathrm{m}$. They are vast and divided into three zones - shallow, central and deep. In the shallow area (0-4 $\mathrm{m})$ Sphagnum is scattered $(\mathrm{F}=50 \%)$ and grows among shoots of emerged plants. Due to constant disturbances caused by wavy motion and water level variations in the lake, the settlement index is low $(3.8 \pm 8.8$ g d.w. $\mathrm{m}^{-2}$ ). The optimum conditions for population development occur in the central part of the area which is located below the thermocline and wave agitation $(4-8 \mathrm{~m})$. 


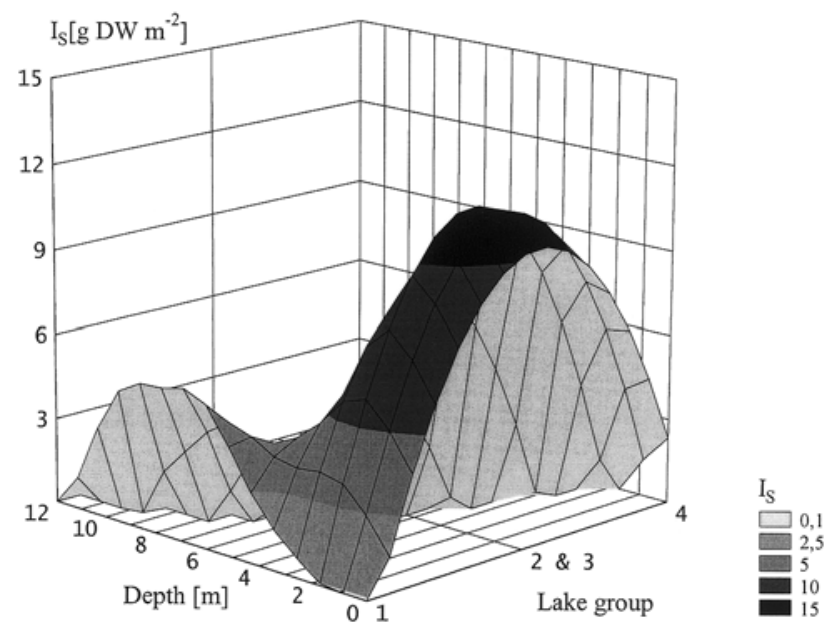

Fig. 5. Model of changes in Fontinalis antipyretica populations in lakes ranging from oligo- (1) to polyhumic (4). $\mathrm{I}_{S}$ - settlement index of the population area.

Sphagnum denticulatum forms compact and vast fields here. $\mathrm{I}_{\mathrm{S}}$ and $\mathrm{I}_{\mathrm{D}}$ are very high (156.3 \pm 129.4 ; max. $297.8 \mathrm{~g}$ d.w. $\mathrm{m}^{-2}$ and $10.2 \pm 12.4$, max. $51.4 \mathrm{~g} \mathrm{~d}$.w. $0.1 \mathrm{~m}^{-2}$, respectively). In the deep part of the area where the population occurs (8$-9 \mathrm{~m})$, the aggregations are much smaller and the $\mathrm{I}_{\mathrm{S}}$ index is low $\left(3.8 \pm 2.0 \mathrm{~g} \mathrm{~d} . \mathrm{w} . \mathrm{m}^{-2}\right)$, although the species frequency is still very high (Fig. 6 ).

In $\alpha$-meso-, $\beta$-meso- and polyhumic lakes the population areas are increasingly narrower and reach depths of 6,4 and $1 \mathrm{~m}$, respectively. The depth of Sphagnum occurrence is strongly correlated with the DOC content in the water $(r=-0.84)$, water color and visibility $(r=-0.81$ and -0.93$)$. In mesohumic lakes, the shallow population area $(0-1 \mathrm{~m})$ is inhabited by scattered individuals or very small surface aggregations, which are similar to those in oligohumic lakes. Significant differences appear in the center of the area which is in shallower water in the wave disturbance zone. Instead of vast fields, they form small aggregations composed of several individuals. Thus, their $\mathrm{I}_{\mathrm{S}}$ and $\mathrm{I}_{\mathrm{D}}$ are low $\left(7.2 \pm 8.9 \mathrm{~g}\right.$ d.w. $\mathrm{m}^{-2}$ and $0.9 \pm 0.7 \mathrm{~g}$ d.w. $\left.0.1 \mathrm{~m}^{-2}\right)$. The individuals that grow in the deepest part of the population area in $\alpha$-meso- (3-6 m) and $\beta$-mesohumic (2-4 m) lakes have a decreased vitality and resemble etiolated forms. They only form small aggregations and are simply the remains of previously vast fields. Dead shoots are observed below the lower border of the population area; this is the result of the lower area border shifting closer to the lake shores. In polyhumic lakes, the population areas are in very shallow zones $(0-0.5 \mathrm{~m})$. They are narrow and occur only in places protected from wind. The $\mathrm{I}_{\mathrm{S}}$ and $\mathrm{I}_{\mathrm{D}}$ indexes have low values (Fig. 6).

\section{DISCUSSION}

Organic matter, including humic substances (HS), occur in the water and sediments of all soft water lakes. Therefore, it is obvious that plants from soft waters, especially dominants, have adapted through evolution to moderate concentrations of DOM and the environmental conditions created by these substances in the water. However, when DOM are introduced via ditches from drained swamps and

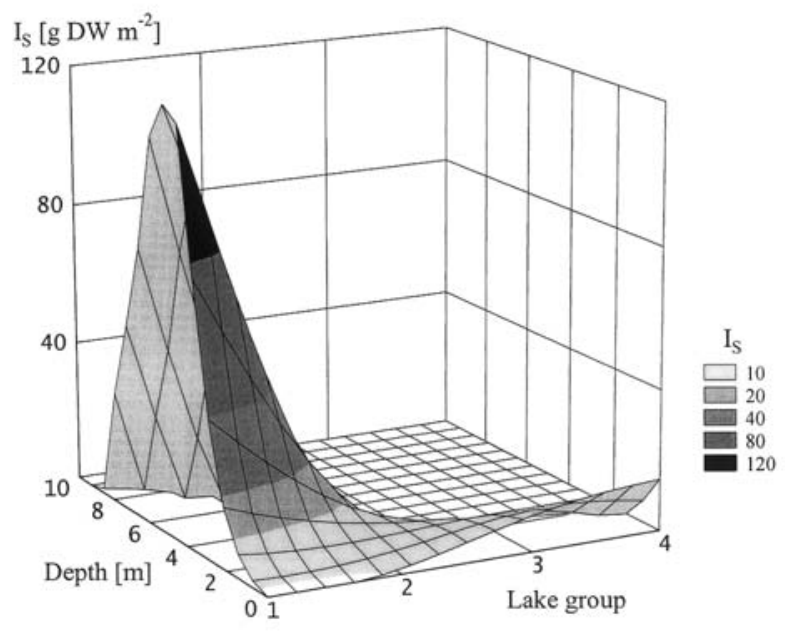

Fig. 6. Model of changes in Sphagnum denticulatum populations in lakes ranging from oligo- (1) to polyhumic (4). $\mathrm{I}_{\mathrm{S}}$ - settlement index of the population area.

peat-bogs, their concentration in the water is many times higher than natural levels (often reaching levels that are 30$50 \times$ higher than normal). This leads to the appearance of plasticity reaction in the plants and changes in the population structure.

The inflow of large amounts of DOM from drained bogs into lakes causes an increase in water color (Table 1). This results in increased light absorption. Colloidal complexes formed by HS scatter light (Wilkinson et al. 1997) and limit the illumination of plant habitats. HS react with water and sediment components thus reducing their availability to plants (Jones 1992; Sunda 1994). The sedimentation of organic matter modifies the sediments and limits the illumination of the habitats. This causes the deepwater populations of Isoëtes lacustris, Sphagnum denticulatum and Fontinalis antipyretica to be "pushed" into shallower habitats where the substratum is often eroded by waves which renders it mineral and not very hydrated (Table 1). The resulting changes in the populations are not only due to the high DOM concentration in the water, insufficient illumination and changes in the amounts of available resources, but also to the disturbances which shallowly located population areas are effected by. Under such conditions, the features of habitats, individuals and populations depend on the intensity and frequency of wavy motion. This causes bottom erosion and the transfer and accumulation of sand (Keddy 1985; Shipley et al. 1989) and leads to habitats becoming barren. It also usually increases the mortality rate in the population, causes generations to rotate faster and influences a shift in reproduction from generative to vegetative (Szmeja 1994a-c).

The dominant species in soft water lakes have various plasticity reaction patterns and different life strategies (Murphy et al. 1990). Among these are species with strategy S (Isoëtes lacustris), R (Lobelia dortmanna; Szmeja 1994c), C (Sphagnum denticulatum) and R-S (Fontinalis antipyretica). As the DOM concentration and changes in habitat increase, the size, fertility and allocation of mass in the organs of individuals begin to change (Figs 1, 3); disintegration of the populations of each species also occurs (Figs 2, 4-6). The intensity and the effects of this process vary for different species and depend greatly on life strate- 
gy. The highest number of negative reactions, manifested by a significant decrease of in size and fertility, was observed in populations of species with strategy S (Isoëtes, Fig. 1), while the fewest were noted for R (Lobelia, Fig. 3) and R-S (Fontinalis).

Isoëtes and Lobelia both belong to the isoetid group of plant life forms; however, their reaction to disturbances in shallow habitats differs. Isoëtes does not tolerate such conditions, so it becomes smaller, lighter and produces fewer spores (Fig. 1). These changes are accompanied by a slower growth rate and individuals development (Szmeja 1994a), which may be a stress reaction to the deficiency of nutrients (Boston and Adams 1987; Nielsen and Sand-Jensen 1991; Paffen and Roelofs 1991). On the other hand, Lobelia is well adapted to habitats at high risk of destruction. Although it is noted that it is smaller and its fertility is lower (Fig. 3), these changes have a low impact on population reproduction since mainly vegetative offspring are created under these conditions (Szmeja 1994a, c).

Fontinalis antipyretica reacts differently than the isoetids. It has the longest, narrowest and most ramified shoots in lakes with high DOM concentrations. According to Barko and Smart (1986) and Boston et al. (1989), this type of shoot modification increases the ability of utilizing additional light portions. It is important to note that Fontinalis in polyhumic lakes inhabits the submerged roots of shore trees so it has no contact with the sediments. Fontinalis shows greater range of tolerance to environmental conditions. According to Karttunen and Toivonen (1995), this moss inhabits waters from oligo- to mesotrophic, from transparent to turbid, from soft to hard and from acidic to alkaline ( $\mathrm{pH}$ 5.7-8.1), and since it creates rhizoids, it also inhabits streams (Welch 1960; Biehle et. al. 1998) and disturbed habitats in lake littorals. Fontinalis has type of R$\mathrm{S}$ strategy, and it tolerates light deficiency and strong agitation caused by wavy motion. It is often the only underwater plant in the polyhumic lakes.

Isoëtes lacustris and Lobelia dortmanna draw resources mainly from the sediments. The allocation of mass in the underground and aboveground organs in both species is similar in lakes without a supply of acidic DOM (Szmeja 1994a). However, when habitats have been transformed by inputs of DOM, changes in this characteristic are more evident in Isoëtes than in Lobelia. As the DOM concentrations rise, the proportion of underground to aboveground mass increases in Isoëtes individuals $(\mathrm{P}<0.05)$, while there is no statistically significant change in Lobelia. Although they derive resources from the same source, the reactions of Isoëtes and Lobelia are different. Sphagnum denticulatum and Fontinalis antipyretica draw mineral substances mainly from the water (Jaynes and Carpenter 1986) and their entire biomass is concentrated in the assimilation surface. Again, although the allocation of mass is similar in these two types of macrophyte, they react differently to inputs of DOM. Therefore, it can be surmised that the macrophyte reaction to increased DOM concentrations and the associated habitat changes are more dependant on life strategy rather than the source from which the species draw resources (sediments or water) and the allocation of mass.

As DOM concentrations rise, the populations of each of the studied species deteriorate (Figs 2, 4-6). This process differs slightly in the various species depending on life strategies. Individuals from Isoëtes and Sphagnum populations are eliminated throughout the area. This process is the most intense in the deep and central parts. This lead to narrower population areas and significant decreases in the frequency and settlement index throughout the area (Figs 2,6).

When DOM concentrations are similar, the disintegration of populations of Fontinalis and Lobelia is smaller than that of Isoëtes and Sphagnum. This is manifested by a smaller decrease in the settlement and aggregation density indexes (Figs 4, 5). In populations of Lobelia only the area decreases significantly (Fig. 4). Fontinalis can also survive in the shallow littoral, and in mesohumic lakes the settlement index is even higher than that in oligohumic lakes (Fig. 5). This species can occur in basins with high DOM concentrations, but it must have a solid substrate which it can attach to.

The disintegration of the vegetation structure in the ecosystems of soft water lake results from the strong reduction in the density of the dominant population. This leads to a decrease in the number and density of its aggregations. The increased voids between the aggregations and the greater contribution of dead plant patches are additional symptoms of such processes. The extinction of the dominant can occur throughout the population area or only at its depth border, as is the case with Lobelia. The general pattern of population disintegration is similar for dominants in soft water lakes and is based on the elimination of individuals mainly from the deep and central parts of the population area. The remainder of the populations in the most shallow and best illuminated part of the area are more exposed to disturbances. Only plants that are resistant to such disturbance (Lobelia, Fontinalis) can survive in such habitats.

\section{ACKNOWLEDGEMENTS}

We wish to thank Dr. Krzysztof Banaś and Dr. Krzysztof Gos for their assistance in field and laboratory work and to Jennifer Zielińska for translating the text into English. Funding was provided by grant number 6 PO4 G 09918 and 3 PO4 G 08122 from the Polish State Committee for Scientific Research.

\section{LITERATURE CITED}

BARKO J.W., SMART R.M. 1986. Sediment-related mechanisms of growth limitation in submersed macrophytes. Ecology 67: 1328-1340.

BIEHLE G., SPATZ C., SPECK T. 1998. Hydrodynamics and biomechanics of the submerged water moss Fontinalis antipyretica - a comparison of specimens from habitats with different flow velocities. Bot. Acta 111: 42-50.

BOCIĄG K., SZMEJA J. 2001. Degeneration of the vegetation of soft water lakes under the influence of humic substances. Pol. J. Ecol. 49: 309-328.

BOSTON H.L., ADAMS M.S. 1987. Productivity, growth and photosynthesis of two small "isoëtid" plants, Littorella uniflora and Isoëtes macrospora. J. Ecol. 75: 333-350.

BOSTON H.L., ADAMS M.S., MADSEN J.D. 1989. Photosynthetic strategies and productivity in aquatic systems. Aquat. Bot. 34: 27-57.

CLESCERI L.S., GREENBERG A.E., TRUSELL R.R. 1989. Standard methods for the examination of water and waste water. American Public Health Association, Washington, pp. 1-1042. 
CURTIS P.J. 1998. Climatic and hydrologic control of DOM concentration and quality in lakes. In: Hessen D.O., Tranvik L.J., (eds), Aquatic humic substances. Springer-Verlag, Berlin Heidelberg, pp. 93-105.

DE HAAN H. 1992. Impacts of environmental changes on the biogeochemistry of aquatic humic substances. Hydrobiologia 229: 59-71.

FALIŃSKI J.B., VENANZONI R. 1991. Large-scale ecological map of synusial structure of the forest communities in the Pichtovka study area. In: Faliński, J.B., Pedrotti, F. (eds), Southwestern Siberian Taiga project. Phytocoenosis 3 (N.S.), Archiv. Geobot. 2: 79-82.

FRIMMEL F.H. 1994. Photochemical aspects related to humic substances. Environm. Intern. 20: 373-386.

GILLET F., GALLANDAT J.D. 1996. Integrated synusial phytosociology: some notes on a new, multiscalar approach to vegetation analysis. J. Veg. Sci: 7, 13-18.

GÓRNIAK A. 1996. Substancje humusowe i ich rola w funkcjonowaniu ekosystemów słodkowodnych. Diss. Univ. Warsaw 448: 1-151. (in Polish)

GORHAM E., UNDERWOOD J.K., MARTIN F.B., OGDEN J.G. 1986. Natural and anthropogenic causes of lake acidification in Nova Scotia. Nature 324: 451-453.

GRIME J.P. 1979. Plant strategies and vegetation processes. John Wiley, Chichester.

GUILDFORD S.J., HEALEY F.P., HECKY R.E. 1987. Depression of primary production by humic matter and suspended sediment in limnocorral experiments at Southern Indian Lake, northern Manitoba. Can. J. Fish. Aquat. Sci. 44: 1408-1417.

HESSEN D.O., TRANVIK L.J. 1998. Aquatic humic matter: from molecular structure to ecosystem stability. In: Hessen, D.O., Tranvik, L.J. (eds), Aquatic humic substances. SpringerVerlag, Berlin Heidelberg, pp. 333-342.

JAYNES M.L., CARPENTER S.R. 1986. Effects of vascular and nonvascular macrophytes on sediment redox and solute dynamics. Ecology 67: 875-882.

JONES R.I. 1992. The influence of humic substances on lacustrine planktonic food chains. Hydrobiologia 229: 73-91.

KARTTUNEN K., TOIVONEN H. 1995. Ecology of aquatic bryophyte assemblages in 54 small Finnish lakes and their changes in 30 years. Ann. Bot. Fennici 32: 75-90.

KEDDY P.A. 1985. Wave disturbance on lakeshores, and the within-lake distribution of Ontario's Atlantic Coastal Plain flora. Can. J. Bot. 68: 656-660.

KESKITALO J., ELORANTA P. 1999. Limnology of Humic Waters. Backhuys Publishers, Leiden, pp. 1-284.

KINNIBURGH D.G., MILNE C.J., BENDDETTI M.F., PINHEIRO J.P., FILIUS J., KOOPAL L.K., VAN RIEMSDIJK W.H. 1996. Metal ion binding by humic acid: application of the NICA-Donnan Model. Environ. Sci. Technol. 30: 1687-1698.

KRUSKAL W.H., WALLIS W.A. 1952. Use of ranks in one-criterion variance analysis. J. Am. Stat. Ass. 47: 583-621.

KULBERG A., BISHOP K.H., HARGEBY A., JANSON M., PETERSEN R.C. 1993. The ecological significance of dissolved organic carbon in acidified water. Ambio 22: 331-337

McKNIGHT D.M., AIKEN G.R. 1998. Sources and age of aquatic humus. In: Hessen, D.O., Tranvik, L.J. (eds), Aquatic humic substances. Springer-Verlag, Berlin-Heidelberg, pp. 9-40.
MOORE T.R. 1987. An assessment of a simple spectrophotometric method for the determinaton of dissolved organic carbon in freshwaters. New Zeal. J. Mar. Fresh. Res. 21: 585-589

MURPHY K.J, RØRSLETT B., SPRINGUEL I. 1990. Strategy analysis of submerged lake macrophyte communities, an international example. Aquat. Bot. 36: 303-323.

NIELSEN S.L., SAND-JENSEN K. 1991. Variation in growth rates of submerged rooted macrophytes. Aquat. Bot. 39: 109-120 .

PAFFEN B.G.P., ROELOFS J.G.M. 1991. Impact of carbon dioxide and ammonium on the growth of submerged Sphagnum cuspidatum. Aquat. Bot. 40: 61-71.

PICKETT S.T., WHITE P.S. 1985. The ecology of natural disturbances and patch dynamics. Academic Press, Orlando.

SCHINDLER D.W., CURTIS P.J., PARKER B.R., STAINTON M.P. 1996. Consequences of climate warming and lake acidification for UV-B penetration in North American boreal lakes. Nature 379: 705-708.

SCHINDLER D.W., CURTIS P.J. 1997. The role of DOC in protecting freshwaters subjected to climating warming and acidification from UV exposure. Biogeochemistry 36: 1-8.

SHIPLEY B., KEDDY P.A., MOORE D.R.J., LEMKY K. 1989. Regeneration and establishment strategies of emergent macrophytes. J. Ecol. 77: 1093-1110.

STEARNS S.C. 1992. The evolution of life histories. Oxford Univ. Press, Oxford, pp. 1-248.

STEWART A.J., WETZEL R.G. 1983. Influence of dissolved humic materials on carbon assimilation and alkaline phosphatase activity in natural algal-bacterial assemblages. Fresh. Biol. 12: 369-380.

SUNDA W.G. 1994. The influence of nonliving organic matter on the availability and cycling of plant nutrients in seawater. In: Zepp, R.G., Sonntag, C. (eds), Role of nonliving organic matter in the Earth's carbon cycle. John Wiley \& Sons, Inc., New York, pp 191-207.

SZMEJA J. 1994a. An individual's status in populations of isoetid species. Aquatic Bot. 48: 203-224.

SZMEJA J. 1994b. Dynamics of the abundance and spatial organization of isoetid populations in an oligotrophic lake. Aquat. Bot. 49: 19-32.

SZMEJA J. 1994c. Effect of disturbances and interspecific competition in isoetid populations. Aquatic Bot. 24: 225-238.

SZMEJA J. 2000. Tendencies of changes in the flora and vegetation structure of Pomeranian lakes under the influence oh humic substances. In: Jackowiak, B., Żukowski, W. (eds), Mechanisms of anthropogenic changes of the plant cover. Bogucki Wyd. Naukowe, Poznań, pp. 85-98.

THURMAN E.M. 1985. Organic geochemistry of natural waters. Martinus Nijhoff, Dordrecht, pp. 1-512.

WELCH W. 1960. Monograph of Fontinalaceae. Martinus Nijhoff, The Hague, pp. 1-357.

WETZEL R.G. 1983. Limnology. W.B. Saunders Co., Philadelphia, pp. 1-793.

WILKINSON K.J., NEGRE J.C., BUFFLE J. 1997. Coagulation of colloidal material in surface waters: the role of natural organic matter. J. Cont. Hydr. 26: 229-243. 